\title{
Intervensi Pengendalian dalam Sistem Pengendalian Manajemen dan Kaitannya dengan \\ Kinerja Perusahaan
}

\author{
Agung Praptapa, Hijroh Rokhayati \\ Fakultas Ekonomi Universitas Jenderal Soedirman \\ Jalan Prof. Dr. H.R. Boenyamin No.708 Grendeng Purwokerto \\ Email:praptapa@yahoo.com; hijroh.akt@gmail.com
}

\begin{abstract}
This research is to examine the effect of management control system in water supply firm to the firm performance when some control interventions exist. The case is derived from water supply firm in Banyumas Regency. In this research the effect of result control, action control, personnel control, and cultural control to the firm performance is examined and control intervention is positioned as moderating variable. Data was obtained by using questionnaire sent to employees, from top management to the lowest level. This research uses regression analysis and Moderated Regression Analysis (MRA) to test hypothesis.

The result indicates that result control, personnel control and cultural control affect performance. Action control has no effect to performance. Control intervention moderates the relationship between management control system and performance, however, individually control intervention just moderate the effect of personnel control and cultural control to performance. Control intervention does not moderate the effect of result control and action control to performance.
\end{abstract}

Keywords: Management Control System, Result Control, Action Control, Personnel Control, Cultural Control, Intervention, Performance.

\section{Pendahuluan}

Otonomi daerah yang berlaku di Indonesia mendorong pemerintahan daerah untuk meningkatkan pendapatan asli daerah, yang salah satunya adalah melalui perusahaan daerah. Perusahaan daerah dapat dimiliki oleh pemerintah daerah provinsi seperti Bank Daerah, BPR (Bank Perkreditan Rakyat) atau BKK (Badan Kredit Kecamatan), dan Rumah Sakit. Perusahaan Daerah dapat pula dimiliki oleh pemerintah daerah kabupaten atau kota seperti Perusahaan Daerah Air Minum (PDAM), BPR/BKK, dan Rumah Sakit Umum Daerah (RSUD).

Karena perusahaan daerah dimiliki oleh pemerintah daerah, maka perusahaan daerah tersebut harus mengikuti ketentuan dan peraturan yang berlaku di masing-masing daerah. Pimpinan perusahaan daerah dipilih oleh pemerintah daerah dan beberapa keputusan strategis harus mendapatkan persetujuan dari pemerintah daerah. Dengan demikian, sangat dimungkinkan terdapatnya intervensi dari pemerintah daerah selaku pemilik perusahaan dalam operasional perusahaan. Intervensi dari pemilik perusahaan merupakan suatu hal yang wajar karena pemilik mempunyai hak dalam pengendalian perusahaan atau yang dikenal sebagai ownership control right (Zuoping, 2011).

Salah satu tujuan dari perusahaan daerah adalah untuk meningkatkan Pendapatan Asli Daerah (PAD). Sebagai konsekuensinya, perusahaan daerah dituntut untuk menghasilkan laba tanpa meninggalkan aspek pelayanan kepada masyarakat. Dengan adanya target menghasilkan laba ini, perusahaan daerah

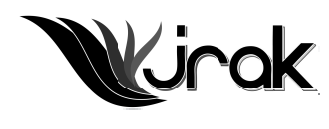

Jurnal Reviu Akuntansi dan Keuangan ISSN: 2088-0685 Vol.2 No. 2, Oktober 2012 Pp 275-286 
Intervensi Pengendalian... harus dikelola secara professional sebagaimana perusahaan pada umumnya. Dilema muncul di sini karena perusahaan daerah dituntut untuk dikelola secara professional namun dimungkinkan adanya intervensi yang dapat mempengaruhi kinerja perusahaan. Intervensi tidak selamanya berakibat negatif, namun dapat pula berakibat positif. Keberadaan intervensi pengendalian di perusahaan daerah ini menjadi penting untuk diteliti karena akan mempengaruhi kinerja perusahaan, dimana kinerja perusahaan merupakan tuntutan pemerintah daerah kepada perusahaan daerah. Keberhasilan suatu perusahaan daerah juga dilihat dari kinerjanya.

Untuk menjaga agar kinerja yang telah ditargetkan dapat dicapai, perusahaan perlu menerapkan Sistem Pengendalian Manajemen (Merchant dan Van der Steede, 2007). Namun demikian, seberapa jauh Sistem Pengendalian Manajemen di suatu perusahaan daerah berpengaruh terhadap kinerja saat terdapat intervensi pengendalian masih jarang diteliti. Penelitian-penelitian sebelumnya yang mengkaitkan Sistem Pengendalian Manajemen dan kinerja mengabaikan keberadaan intervensi pengendalian.

Penelitian ini dilakukan di Perusahaan Daerah Air Minum (PDAM) Kabupaten Banyumas sebagai salah satu bagian dari penelitian tentang keefektivan sistem pengendalian manajemen di PDAM dalam cakupan yang lebih luas, yaitu cakupan provinsi ataupun nasional. Disamping itu, penelitian ini juga merupakan bagian dari penelitian tentang keefektivan sistem pengendalian manajemen di perusahaan-perusahaan daerah dalam cakupan yang lebih luas pula.

Terdapat beberapa alasan mengapa penelitian ini dilakukan di PDAM Banyumas. Pertama, hampir semua pemerintah daerah kabupaten dan kota memiliki PDAM. Dengan demikian penelitian di PDAM Banyumas dapat diperluas ke penelitian di PDAM lain pada cakupan yang lebih luas. Kedua, PDAM Kabupaten Banyumas dikelola secara professional dan menerapkan Sistem Pengendalian Manajemen, sehingga penelitian tentang keefektivan sistem pengendalian manajemen ini dilakukan pada perusahaan yang menerapkan sistem pengendalian manajemen. Ketiga, terdapat ukuran kinerja yang sama bagi PDAM yang ada di seluruh Indonesia, sehingga penelitian ini dapat diperbandingkan dengan penelitian sejenis di kabupaten lain di Indonesia. Keempat, penelitian yang mengkaitkan sistem pengendalian manajemen dengan kinerja saat terdapatnya intervensi pengendalian masih jarang dilakukan sehingga penelitian ini dapat menutup kesenjangan tersebut.

Penelitian ini dilakukan untuk menjawab pertanyaan penelitian apakah sistem pengendalian manajemen dengan adanya intervensi pengendalian berpengaruh terhadap kinerja. Sistem pengendalian manajemen disini meliputi result control, action control, personnel control, dan cultural control (Merchant dan Van der Stede, 2007).

Tujuan dari penelitian ini adalah:

1. Untuk menguji pengaruh result control terhadap kinerja perusahaan.

2. Untuk menguji pengaruh action control terhadap kinerja perusahaan.

3. Untuk menguji pengaruh peronnel control terhadap kinerja perusahaan.

4. Untuk menguji pengaruh cultural control terhadap kinerja perusahaan.

5. Untuk menguji apakah control intervention memoderasi hubungan antara management control systems dengan kinerja perusahaan.

\section{Pengembangan Hipotesis}

\section{Pengendalian Hasil dan Kinerja Perusahaan}

Pengendalian hasil adalah suatu sistem pengendalian yang mengarahkan agar orang-orang yang ada di dalam organisasi memperoleh hasil kerja seperti yang diharapkan. Pengendalian hasil merupakan bentuk meritocracies, yaitu 
penghargaan diberikan berdasarkan hasil, prestasi, atau kinerja, atau disebut juga sebagai pay-for-performance (Merchant dan Van der Stede (2007).

Dalam pengendalian hasil harus dipastikan hasil apa yang diharapkan oleh organisasi bagi suatu unit organisasi maupun individu di dalam organisasi. Untuk itulah maka dimensi kinerja harus didefinisikan dengan jelas. Kejelasan dimensi kinerja akan memberikan arah bagi karyawan untuk melihat apa yang penting bagi perusahaan. Definisi kinerja yang jelas akan mengurangi kebingungan karyawan karena kinerja yang harus dipenuhi unit organisasi maupun orangorang dalam organisasi jelas.

Disamping dimensi kinerja, diperlukan pula sistem penilaian kerja yang jelas, sehingga setiap orang memiliki cara pandang yang sama apakah kinerja seseorang cukup memuaskan atau tidak. Penelitian Bryant, Jones, dan Widener (2004) menunjukkan bahwa penilaian kinerja yang jelas akan mendorong orang-orang dalam organisasi untuk berkinerja lebih baik.

Penghargaan dan hukuman (rewards and punishments) merupakan elemen penting lain dalam pengendalian hasil. Penghargaan merupakan bentuk positive reinforcement yang mendorong karyawan untuk berprestasi, dan hukuman yang merupakan negative reinforcement diharapkan akan mendorong karyawan untuk berperilaku sedemikian rupa sehingga terhindar dari posisi tidak berprestasi (Siegel and Marconi, 1989).

Pendefinisian yang jelas tentang dimensi kinerja, pengukuran kinerja yang tepat, penetapan target yang tepat, dan penerapan sistem penghargaan dan hukuman yang tepat akan mendorong karyawan dan unit organisasi untuk berkinerja. Dengan kata lain, pengendalian hasil akan mempengaruhi kinerja perusahaan. Dengan demikian maka dapat diajukan hipotesis sebagai berikut:

H1: Pengendalian hasil berpengaruh positif terhadap kinerja perusahaan.

\section{Pengendalian Tindakan dan Kinerja Perusahaan}

Pengendalian tindakan (action control) adalah bentuk pengendalian untuk memastikan bahwa karyawan melakukan tindakan yang menguntungkan bagi perusahaan dan menghindari tindakan yang merugikan perusahaan (Merchant and Van der Stede, 2007). Pengendalian ini bersifat preventif, yaitu menjaga jangan sampai hal-hal yang tidak diinginkan terjadi dan diketahui pada akhir proses. Tindakan perbaikan dilakukan secepatnya saat diketahui terdapat tindakan yang perlu diperbaiki. Pengendalian tindakan dapat dilakukan melalui empat cara, yaitu pembatasan perilaku (behavioral constraints), pengkajian sebelum tindakan dilakukan (preaction reviews), akuntabilitas tindakan (action accountability), dan pencadangan (redundancy).

Uraian di atas menunjukkan bahwa apabila tindakan yang dilakukan para karyawan terkendali dengan baik maka pencapaian kinerja dapat diharapkan. Dengan kata lain, pengendalian tindakan akan mempengaruhi kinerja perusahaan. Dengan demikian maka dapat diajukan hipotesis sebagai berikut:

H2: Pengendalian tindakan berpengaruh positif terhadap kinerja perusahaan.

\section{Pengendalian Orang dan Kinerja Perusahaan}

Merchant dan Van der Stede (2007) menyatakan bahwa pengendalian orang (personnel control) merupakan bentuk pengendalian yang memungkinkan seseorang untuk mengendalikan diri sendiri. Hal ini dibangun dari suatu pemahaman bahwa pada dasarnya manusia memiliki kecenderungan untuk mengendalikan diri sendiri dan memotivasi diri sendiri. Pengendalian orang dilakukan untuk memastikan bahwa karyawan memahami apa yang diinginkan oleh perusahaan. Hal ini dapat dilakukan apabila perusahaan memiliki sumberdaya manusia dengan kualitas yang diharapkan. Pengendalian orang ini dilakukan sejak seleksi dan 
Intervensi Pengendalian... penempatan karyawan, pelatihan yang disiapkan untuk karyawan, dan juga perancangan tugas (job design) yang baik.

Untuk menjamin bahwa kinerja perusahaan tercapai maka kebutuhan karyawan dan tingkat keahlian maupun kepribadian yang diinginkan harus direncanakan secara cermat. Proses penerimaan karyawan dan penempatan karyawan harus terbuka dengan sistem yang jelas dan tepat. Pelatihan yang tepat harus disiapkan untuk karyawan yang sudah ada di perusahaan. Training dimaksudkan untuk meningkatkan kemungkinan agar karyawan dapat memberikan kinerja sesuai yang diharapkan dan juga untuk mempersiapkan diri agar kayawan siap menghadapi tuntutan perubahan. Pelatihan tidak harus dalam bentuk pelatihan formal, namun dapat juga dilakukan melalui pelatihan informal. Untuk memotivasi karyawan untuk berkinerja sesuai yang diharapkan, karyawan memerlukan kepastian atas masa depan mereka di perusahaan. Untuk itulah maka rancangan tugas dan rancangan karir bagi karyawan perlu disiapkan secara baik dan terbuka.

Sistem penerimaan karyawan yang baik dan terbuka, sistem penempatan pegawai yang tepat dan terbuka, kesempatan pelatihan yang cukup dan berkualitas, serta ranncangan tugas dan karir yang baik akan mendorong karyawan untuk berkinerja. Sistem pengendalian orang akan mempengaruhi kinerja perusahaan. Dengan demikian dapat diajukan hipotesis sebagai berikut:

H3: Pengendalian orang berpengaruh positif terhadap kinerja perusahaan.

\section{Pengendalian Kultural dan Kinerja Perusahaan}

Pengendalian kultural dirancang untuk mendorong para karyawan untuk saling mengendalikan antar satu orang dengan orang lainnya, untuk memberikan arahan dan tekanan dari suatu kelompok (group pressure) kepada individu yang bertindak tidak sesuai dengan norma dan nilai yang berlaku di perusahaan (Merchat dan Van der Stede, 2007).

Pengendalian kultural dapat dilakukan melalui adanya kesepakatan dan pemahaman bersama atas apa yang akan dilakukan (codes of conduct), melalui kode etik atau melalui motto atau nilai yang disepakati dalam perusahaan, yang harus dipatuhi dan diyakini oleh setiap karyawan. Bentuk pengendalian kultural lainnya adalah melalui penghargaan berbasis kelompok (group-based rewards), rotasi tugas (intra-organizational transfers), pengaturan fisik dan sosial (physical and social arrangements), dan pemberian contoh dari atasan (tone at the top).

Kesepakatan dan pemahaman bersama atas apa yang akan dilakukan melalui adanya kode etik, motto perusahaan, visi dan misi perusahaan, ataupun filosofi perusahaan yang dimaksudkan agar seluruh karyawan merasa terikat satu dengan lainnya di dalam mewujudkan misi perusahaan. Kesepakatan dan pemahaman yang jelas, sederhana, dan memberi semangat akan mendorong seluruh karyawan untuk bersatu melakukan pekerjaan sesuai dengan yang seharusnya untuk mencapai tujuan perusahaan.

Penghargaan berbasis kelompok akan mendorong anggota organisasi untuk mengajak rekan kerjanya di dalam kelompoknya untuk bersama-sama melakukan pekerjaan yang terbaik bagi kelompoknya dan juga bagi perusahaan. Riset yang telah dilakukan oleh Kruse (1992) menunjukkan bahwa penghargaan berbasis kelompok berpengaruh positif terhadap motivasi dan kinerja.

Rotasi kerja dimaksudkan untuk menyebarkan kultur positif ke karyawan lain. Rotasi tugas akan meningkatkan rasa kebersamaan bagi karyawan dan akan meningkatkan kinerja perusahaan secara keseluruhan. Disamping itu, rotasi tugas juga akan mengurangi kemungkinan kecurangan yang dilakukan oleh karyawan (KPMG LLP, 1999).

Pengaturan ruangan, pengaturan istilah, pengaturan berbusana dan pengaturan dalam hal bersosialisai juga merupakan cara yang efektif di dalam mela- 
kukan pengendalian kultural. Ruangan yang memungkinkan karyawan untuk bekerja produktif akan mendorong kinerja perusahaan. Ruangan yang dirancang sedemikian rupa sehingga antara karyawan dapat saling belajar dan saling mengendalikan juga akan meningkatkan kinerja. Istilah-istilah yang positif dan memberikan semangat kerja juga akan mendorong kinerja.

Kultur perusahaan sangat bergantung pada bagaimana para pimpinan bertindak. Pimpinan harus menunjukkan teladan karena pimpinan sering dijadikan model oleh karyawan. Riset menunjukkan bahwa sukses perusahaan bermula dari atas dan kecurangan yang terjadi dalam perusahaan juga bermula dari atas (Jenkins, 2002; Merchant and Van der Stede, 2007)

Uraian di atas menunjukkan bahwa pengendalian kultural berperan penting dalam menciptakan kinerja perusahaan. Pengendalian kultural berpengaruh terhadap kinerja perusahaan. Dengan demikian dapat diajukan hipotesis sebagai berikut:

H4: Pengendalian kultural berpengaruh positif terhadap kinerja perusahaan.

\section{Intervensi Pengendalian dan Kinerja Perusahaan}

Intervensi pengendalian terjadi saat terdapat pihak-pihak tertentu di luar perusahaan turut serta melakukan campur tangan dalam sistem pengendalian manajemen yang telah ditetapkan oleh perusahaan. Intervensi pengendalian dapat berupa tindakan yang mendorong kinerja (encouraging) dan dapat pula yang menghambat kinerja (discouraging). Intervensi pengendalian terutama yang dilakukan pemilik merupakan seseuatu yang wajar karena pemilik memiliki hak untuk melakukan pengendalian (Zuoping, 2011).

Intervensi pengendalian dapat mendorong pengendalian hasil di dalam kaitannya dengan pencapaian kinerja perusahaan. Penetapan target yang menantang tetapi memungkinkan untuk dicapai (chalanging but achievable) yang ditetapkan oleh pemangku kepentingan tertentu akan mendorong karyawan dan perusahaan untuk mencapai target yang ditetapkan. Namun mungkin juga terjadi justru intervensi pengendalian akan mengganggu perusahaan dalam mencapai kinerja yang diinginkan. Di dalam bahasa penelitian hal tersebut berarti intervensi pengendalian memoderasi hubungan antara pengendalian hasil dengan kinerja perusahaan (Cooper and Schindler, 2008).

Dalam pengendalian tindakan, intervensi pengendalian dapat pula terjadi saat ada pihak-pihak tertentu di luar organisasi turut campur tangan di dalam mekanisme pengendalian tindakan. Terdapat kemungkinan atas intervensi tersebut karyawan dapat melakukan tindakan yang lebih baik dan mendorong kinerja, meskipun terdapat kemungkinan pula karyawan menjadi tidak yakin atas apa tindakan yang mereka lakukan sehingga justru berakibat negatif terhadap pencapaian kinerja. Disini berarti intervensi pengendalian memoderasi hubungan antara pengendalian tindakan dengan kinerja perusahaan.

Intervensi pengendalian sering terjadi dalam pengendalian orang maupun kultural. Intervensi dalam penerimaan pegawai dan penempatan pegawai dapat mendorong kinerja namun dapat pula sebaliknya. Hal tersebut terjadi pula di dalam pengendalian kultural. Dengan demikian maka intervensi pengendalian memoderasi hubungan antara pengendalian orang dengan kinerja perusahaan, dan intervensi pengendalian memoderasi hubungan antara pengendalian kultural dengan kinerja perusahaan. Dengan demikian dapat diajukan hipotesis sebagai berikut:

H5: Intervensi pengendalian memoderasi hubungan antara sistem pengendalian manajemen dengan kinerja perusahaan. 
Intervensi

Pengendalian...

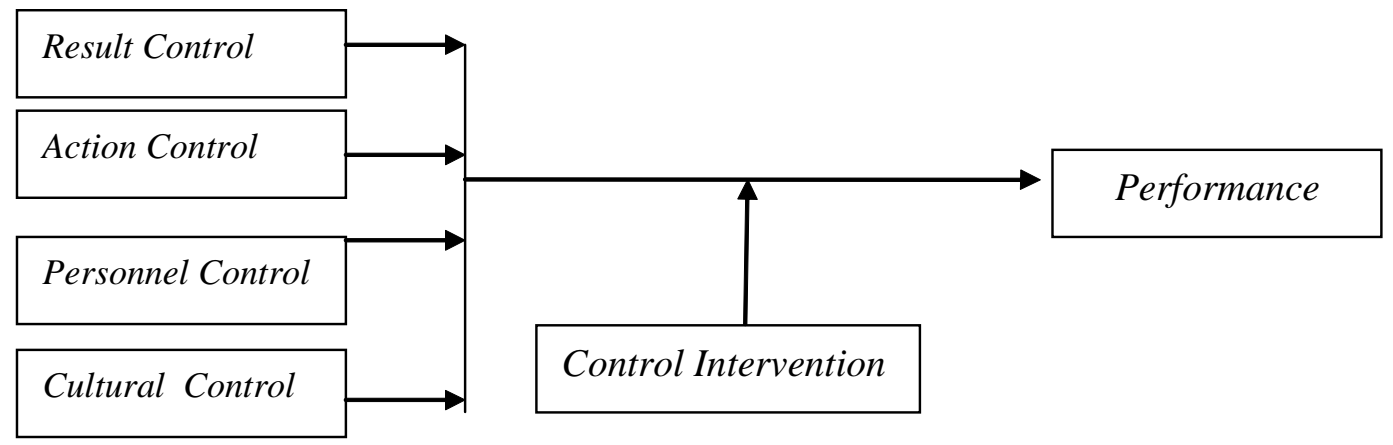

Metoda Penelitian

\section{Teknik Pengumpulan Data}

Penelitian ini merupakan penelitian kuantitatif untuk melihat hubungan sebab akibat antar variabel. Populasi dari penelitian ini adalah seluruh karyawan PDAM Kabupaten Banyumas. Sampel dalam penelitian ini ditentukan berdasarkan stratified dan cluster sampling sehingga mewakili karyawan di berbagai jenjang yang ada di PDAM Banyumas dan juga mewakili semua kantor cabang dan kantor unit yang ada di PDAM Kabupaten Banyumas. Data untuk penelitian ini adalah data primer yang dikumpulkan dengan metode survey dengan menggunakan kuesioner. Objek penelitian ini adalah kinerja PDAM Kabupaten Banyumas. Untuk mengukur kinerja digunakan Balance Scorecard, yaitu suatu pengukuran kinerja yang berimbang antara kinerja financial dan kinerja non financial. Pengukuran kinerja ini akan terdiri dari empat perspektif yaitu perspektif financial (financial perspective), perspektif pelanggan (customer perspective), perspektif bisnis internal (internal business perspective), dan perspektif inovasi dan pembelajaran (innovation and learning perspective).

Data dalam penelitian ini diperoleh dengan menggunakan kuisioner yang berisi beberapa item pernyataan yang berkaitan dengan sistem pengendalian manajemen, intervensi dan kinerja perusahaan. Semua pengukuran merupakan pengukuran atas persepsi karyawan. Item kuesioner menggunakan skala 1 sampai dengan skala 4. Skor 1 untuk jawaban sangat tidak setuju atau tidak pernah dan skor 4 untuk jawaban sangat setuju atau sangat sering.

\section{Teknik Analisis Data}

\section{Statistik Deskriptif}

Statistik deskriptif digunakan untuk menggambarkan dan mendeskripsikan variabel-variabel dalam penelitian ini. Analisis yang dilakukan adalah deskripsi nilai ata-rata, standar deviasi, nilai minimum dan nilai maksimum dari setiap variabel.

\section{Uji Kualitas Data}

Untuk menguji kualitas instrumen data maka dilakukan dua uji yaitu validitas dan reliabilitas Untuk menguji data dalam penelitian ini juga dilakukan uji asumsi klasik (normality, multicollinearity dan heterokedastisitas). Pengujian hipotesis menggunakan analisa regresi dengan alat bantu SPSS Versi 16.

\section{Hasil Penelitian}

Responden ini adalah karyawan PDAM Kabupaten Banyumas. Untuk memperoleh data dalam penelitian ini, disebar sebanyak 200 kuesioner, dan kuesioner 
dikembalikan sebanyak 147 kuesioner, sehingga response rate-nya adalah 73,5\%. Dari 147 kuesioner yang dikembalikan terdapat 6 kuesioner yang tidak layak untuk diolah karena diisi tidak lengkap oleh responden sehingga data yang diolah berasal dari 141 kuesioner.

\section{Pengujian Hipotesis dan Pembahasan}

Analisis regresi berganda

Hasil analisis regresi berganda variabel pengendalian hasil, pengendalian tindakan, pengendalian personnel, pengendalian budaya terhadap kinerja perusahaan menggunakan persamaan regresi:

$$
\mathrm{Y}=\beta \mathrm{o}+\beta 1 \mathrm{X} 1+\beta 2 \mathrm{X} 2+\beta 3 \mathrm{X} 3+\beta 4 \mathrm{X} 4+\mathrm{e}
$$

Keterangan:

$\mathrm{Y} \quad=$ Performance

$\mathrm{X} 1=$ Personal Control

$\mathrm{X} 2=$ Result Control

$\mathrm{X} 3=$ Action Control

$\mathrm{X} 4=$ Result Control

e $\quad$ error

\begin{tabular}{lcl}
\hline \multicolumn{1}{c}{ Keterangan } & \multicolumn{1}{c}{$\mathbf{t}$} & Sign \\
\hline Constant & 8.674 & .000 \\
RC & 2.343 & .021 \\
AC & .480 & .632 \\
PC & 4.298 & .000 \\
CC & 5.262 & .000 \\
\hline
\end{tabular}

Tabel 1. Hasil

\section{Pengujian hipotesis pertama (H1)}

Hasil olahan data menunjukkan bahwa t hitung variabel result control (pengendalian hasil) dengan nilai t hitung 2,343 dengan signifikan 0,021 lebih kecil dari alpha 0,05. Hasil ini menunjukkan bahwa hipotesis pengendalian hasil berpengaruh secara positif terhadap kinerja perusahaan (H1) terdukung. Hasil pengujian mendukung Merchant \& Van der Stede (2007) bahwa pengendalian hasil berpengaruh terhadap kinerja. Hal ini menunjukkan bahwa result control yang ada dipandang efektif untuk meningkatkan kinerja.

\section{Pengujian hipotesis ke dua (H2)}

Nilai t hitung untuk pengendalian tindakan (action control) sebesar 0,48 dengan tingkat signifikansi 0.632 yang berarti lebih besar dari 0.05 . Hal ini menunjukkan bahwa hipotesis pengendalian tindakan berpengaruh positif terhadap kinerja perusahaan (H2) tidak terdukung. Hasil ini tidak sesuai dengan Merchant \& Van der Stede (2007) yang menyatakan bahwa pengendalian tindakan yang baik akan efektif untuk menjaga kinerja. Perbedaan temuan ini bisa dikarenakan action control yang ada di PDAM Banyumas lebih fokus kepada pekerjaan-pekerjaan yang lebih teknis sehingga tidak mendapatkan efek dari intervensi dari pihak eksternal dalam kaitannya dengan pengaruhnya terhadap kinerja perusahaan. 
Intervensi

Pengendalian...

\section{2}

Tabel 2. Nilai

koefisien determinasi $\mathrm{H} 1-\mathrm{H} 4$

\section{Pengujian hipotesis ke tiga (H3)}

Nilai t hitung untuk pengendalian personnel sebesar 4,298 pada tingkat signifikan 0.000, yang berarti lebih besar dari alpha 0.05. Hal ini menunjukkan bahwa hipotesis pengendalian personnel berpengaruh positif terhadap kinerja perusahaan (H3) terdukung. Hal ini sejalan dengan Merchant \& Van der Stede (2007) yang berpendapat bahwa personnel control memberikan kejelasan bagi perusahaan, bahwa karyawan yang dibutuhkan sesuai dengan harapan organisasi (seperti pengalaman dan kecerdasan) dan sumber daya (informasi waktu) untuk melakukan pekerjaan yang baik sehingga berpengaruh positif terhadap kinerja.

\section{Pengujian hipotesisi ke empat (H4)}

Nilai t hitung untuk pengendalian kultural (cultural control) sebesar 5,264 pada tingkat signifikan 0.000 yang lebih kecil dari alpha 0.05 . Hal ini menunjukkan bahwa hipotesis yang menyatakan pengendalian kultural berpengaruh positif terhadap kinerja perusahaan (H4) terdukung. Hasil ini sejalan dengan penelitian Malmi \& Brown (2008) yang berpendapat bahwa nilai-nilai memiliki efek pada perilaku melalui tiga tingkat proses. Tingkat pertama mengacu pada saat melakukan seleksi individu yang sejalan dengan nialai-nilai perusahaan. Pada tingkat kedua individu disosialisasikan dalam upaya untuk mengubah mereka dalam mematuhi nilai-nilai organisasi. Akhirnya, karyawan berperilaku sesuai dengan budaya perusahaan.

Dengan uji F pada Tabel 4 (lihat lampiran) diperoleh nilai F hitung sebesar 62,085 dengan tingkat signifikan 0,000 lebih rendah dari 0,005 yang berarti secara bersama-sama variabel Sistem Pengendalian Manajemen berpengaruh positif terhadap kinerja perusahaan.

\begin{tabular}{cccc}
\hline Model & $\mathbf{R}$ & $\mathbf{R}^{2}$ & Adjusted $\mathbf{R}^{2}$ \\
\hline 1 & .804 & .646 & .636 \\
\hline
\end{tabular}

Dari Tabel 2 dapat diketahui hasil analisis regresi secara keseluruhan menunjukkan nilai $\mathrm{R}$ sebesar 0,804 . Hal ini berarti bahwa hubungan antara variabel sistem pengendalian manajemen dan kinerja perusahaan mempunyai hubungan yang kuat sebesar $80,4 \%$. Nilai koefisien determinasi $\left(\mathrm{R}^{2}\right)$ sebesar 0.646 menunjukkan bahwa variabel dependen (kinerja perusahaan) mampu dijelaskan oleh variabel independen yaitu sistem pengendalian manajemen sebesar $64,6 \%$. Sementara selebihnya 35,4\% dapat dijelaskan oleh faktor-faktor lain di luar model atau tidak dijelaskan dalam penelitian ini.

\section{Uji hipotesis ke lima (H5).}

Untuk menganalisis hipotesis Sistem Pengendalian Manajemen dengan adanya intervensi akan berpengaruh positif terhadap kinerja perusahaan ditunjukkan dengan persamaan sebagai berikut:

$$
\begin{aligned}
& \mathrm{Y}= \beta \mathrm{o}+ \\
& 8 \mathrm{X} 4 . \mathrm{X} 5+\mathrm{X} 1+\beta 2 \mathrm{X} 2+\beta 3 \mathrm{X} 3+\beta 4 \mathrm{X} 4+\beta 5 \mathrm{X} 5+\beta 6 \mathrm{X} 1 . \mathrm{X} 5+\beta 7 \mathrm{X} 2 . \mathrm{X} 5+\beta 7 \mathrm{X} 3 . \mathrm{X} 5+ \\
& \mathrm{Y} \quad=\text { Performance (kinerja perusahaan) } \\
& \mathrm{X} 1 \quad=\text { Personal Control } \\
& \mathrm{X} 2 \quad=\text { Result Control } \\
& \mathrm{X} 3 \quad=\text { Action Control }
\end{aligned}
$$


$\mathrm{X} 1 . \mathrm{X} 5=$ interaksi variable $\mathrm{X} 1$ dan $\mathrm{X} 5$

$\mathrm{X} 2 . \mathrm{X} 5=$ interaksi antara variable $\mathrm{X} 2$ dan $\mathrm{X} 5$

$\mathrm{X} 3 . \mathrm{X} 5=$ interaksi antara variable $\mathrm{X} 3$ dan $\mathrm{X} 5$

$\mathrm{X} 4 . \mathrm{X} 5=$ interaksi antara variable $\mathrm{X} 4$ dan $\mathrm{X} 5$

âo $=$ Konstanta

â1-8 = Koefisien regresi variable X1-X8

$\mathrm{e}=$ error

Model analisis variable moderating (MRA) diolah menggunakan SPSS Versi 16. Hipotesis lima (H5) menyatakan bahwa pengaruh sistem pengendalian manajemen dimoderasi oleh intervensi terhadap kinerja perusahaan. Hal ini berarti bahwa adanya intervensi terhadap sistem pengendalian manajemen yang terdiri dari pengendalian tindakan, pengendalian hasil, pengendalian orang dan pengendalian budaya akan semakin mendorong kinerja perusahaan.

\begin{tabular}{lcc}
\hline Keterangan & $\mathbf{F}$ & Sign \\
\hline Regression & 56,021 & 0,000 \\
\hline
\end{tabular}

Tabel 3 menunjukkan bahwa pengujian variabel moderating intervensi terhadap variabel sistem pengendalian manajemen dan kinerja perusahaan menunjukkan hasil yang signifikan yaitu nilai signifikansi sebesar 0.000 yang berarti lebih kecil dari 0.005. Sehingga dapat disimpulkan bahwa variabel intervensi memoderasi hubungan sistem pengendalian manajemen dan kinerja perusahaan (H5) terdukung. Hal ini menunjukkan bahwa intervensi yang dilakukan oleh pihak eksternal perusahaan daerah tersebut akan mempengaruhi kinerja.

\begin{tabular}{cccc}
\hline Model & $\mathbf{R}$ & $\mathbf{R}^{2}$ & Adjusted $\mathbf{R}^{2}$ \\
\hline 1 & .891 & .794 & .780 \\
\hline
\end{tabular}

Tabel 4 menunjukkan bahwa untuk pengujian pengaruh moderasi dengan nilai selisih mutlak menunjukkan nilai $R^{2}$ sebesar 0.794 yang berarti pengaruh sistem pengendalian intern yang dimoderasi oleh intervensi dapat menjelaskan variabel kinerja perusahaan sebesar 79,4\%, sedangkan 21,6\% dipengaruhi oleh variabel lain yang tidak dibahas dalam penelitian ini.

\section{Uji signifikansi paramameter individual (uji t statistik)}

Semua variabel yang dimasukkan dalam MRA berpengaruh secara signifikan terhadap kinerja perusahaan (Tabel 5). Variabel result control memberikan nilai koefisien -0,688 dengan tingkat signifikan 0.492 yang berarti tidak signifikan karena nilai diatas 0,005. Variabel action control memberikan nilai koefisien 0,369 dengan tingkat signifikan 0.713 yang berarti tidak signifikan karena nilai diatas 0,005. Variabel personnel control memberikan nilai koefisien 3,081 dengan tingkat signifikan 0.003 yang berarti signifikan karena nilai dibawah 0,005 . Variabel cultural control memberikan nilai koefisien -4,677 dengan tingkat signifikan 0.000 yang berarti signifikan karena nilai dibawah 0,005 . Variabel intervention memberi-

Tabel 3. Hasil uji F variabel moderating

Tabel 4.

Nilai koefisien determinasi H5 
Intervensi Pengendalian...

284 kan nilai koefisien -3,109 dengan tingkat signifikan 0.002 yang berarti signifikan karena nilai dibawah 0,005. Variabel moderasi antara result control dan intervention memberikan nilai koefisien sebesar 0,818 pada tingkat signifikan 0.415 yang berarti tidak signifikan karena nilai signifikansi diatas 0,005. Variabel moderasi antara action control dan intervention memberikan nilai koefisien sebesar -0,432 pada tingkat signifikan 0,666 yang berarti tidak signifikan karena nilai signifikansi diatas 0,005. Variabel moderasi antara personnel control dan intervention memberikan nilai koefisien sebesar $-2,699$ pada tingkat signifikan 0.008 yang berarti signifikan karena nilai signifikansi dibawah 0,005. Variabel moderasi antara $\mathrm{cul}^{-}$ tural control dan intervention memberikan nilai koefisien sebesar 5,277 pada tingkat signifikan 0.000 yang berarti signifikan karena nilai signifikansi dibawah 0,005. Dari analisa diatas jika diuji secara individu, maka variabel intervensi hanya memoderasi variabel personnel control dan cultural control terhadap kinerja perusahaan. Hal ini sejalan dengan teori bahwa adanya intervensi dari eksternal perusahaan terhadap pengendalian orang akan dapat mempengaruhi kinerja perusahaan. Intervensi pengendalian tidak memoderasi result control dan action control menunjukkan bahwa result control dan action control efektif digunanakan sebagai strategi pengendalian karena tidak terganggu oleh intervensi.

\begin{tabular}{lccc}
\hline Keterangan & Coefisien & \multicolumn{1}{c}{ T } & \multicolumn{1}{c}{ Sign } \\
\hline (Constant) & 24.731 & 5.661 & .000 \\
RC & -.181 & -.688 & .492 \\
AC & .121 & .369 & .713 \\
PC & 2.043 & 3.081 & .003 \\
CC & -1.851 & -4.677 & .000 \\
INT & .012 & .818 & .415 \\
MODERATING1 & -.008 & -.432 & .666 \\
MODERATING2 & -.103 & -2.699 & .008 \\
MODERATING3 & .119 & 5.277 & .000 \\
MODERATING4 & -.789 & -3.109 & .002 \\
\hline
\end{tabular}

\section{Simpulan, Implikasi, dan Keterbatasan}

\section{Simpulan}

Penelitian ini menunjukkan bahwa di PDAM Kabupatan Banyumas result control, personnel control, dan cultural control berpengaruh positif terhadap kinerja. Namun demikian action control tidak berpengaruh positif terhadap kinerja. Hal ini dapat disebabkan karena action control lebih fokus terhadap hal-hal yang bersifat teknis sehingga karyawan tidak melihat pengaruhnya terhadap kinerja.

Adanya intervensi pengendalian mempengaruhi hubungan sistem pengendalian manajemen dengan kinerja. Namun apabila dilihat secara individual, intervensi pengendalian hanya memoderasi antara personnel control dan cultural control dengan kinerja. Intervensi pengendalian tidak memoderasi result control dan action control terhadap kinerja. Hal ini menunjukkan bahwa result control dan action control lebih tahan terhadap intervensi dari pada personnel control dan cultural control. 
Hasil penelitian yang menunjukkan bahwa sistem pengendalian manajemen berpengaruh terhadap kinerja mengindikasikan bahwa perusahaan perlu merancang dan menerapkan sistem pengendalian manajemen sebaik-baiknya.

Kehadiran intervensi pengendalian yang tidak mengganggu pengaruh result control dan action control terhadap kinerja memberikan masukan kepada perusahaan untuk memperkuat dua jenis pengendalian ini karena lebih tahan terhadap intervensi.

Intervensi pengendalian yang memoderasi pengaruh personnel control dan cultural control terhadap kinerja memberikan masukan kepada perusahaan agar melakukan rancangan ulang dalam dua jenis pengendalian ini karena saat ini masih rentan terhadap intervensi. Artinya, pihak luar perusahaan dapat mengganggu personnel control dan cultural control sehingga perlu dicari jalan keluarnya agar intervensi negatif dapat ter-filter dengan baik.

\section{Keterbatasan}

Penelitian ini tidak melakukan penilaian secara langsung terhadap sistem pengendalian manajemen, intervensi, dan kinerja perusahaan namun hanya berdasarkan persepsi karyawan. Dengan demikian kinerja dalam penelitian ini adalah berdasarkan persepsi karyawan tentang kinerja mereka, bukan merupakan penilaian objektif tentang kinerja dengan penggunakan instrument standar pengukuran kinerja. Demikian pula dengan berapa jauh keefektifan sistem pengendalian manajemen yang ada di perusahaan, bukan merupakan penilaian objektif dari peneliti atau pihak independen lainnya namun merupakan persepsi karyawan. Intervensi pengendalian juga merupakan persepsi karyawan tentang intervensi yang mereka alami, bukan hasil investigasi dari peneliti atau pihak independen lainnya. Penelitian selanjutnya diharapkan dapat melakukan penilaian yang lebih objektif terhadap sistem pengendalian manajemen, intervensi, dan kinerja perusahaan.

Cakupan penelitian ini hanya terbatas pada satu unit bisnis, yaitu PDAM Kabupaten Banyumas. Diharapkan penelitian selanjutnya dapat dilakukan pada cakupan yang lebih luas. Penelitian selanjutnya juga diharapkan dapat dilakukan pada jenis usaha lain dari perusahaan daerah seperti BPR/BKK dan Rumah Sakit sehingga mampu mendapatkan gambaran yang lebih baik bagaimana intervensi pengendalian dapat mempengaruhi hubungan sistem manajemen dengan kinerja di perusahaan daerah.

\section{DAFTAR PUSTAKA}

Anthony, Robert N, and V. Govindarajan. 2007. Management Control Systems, $12^{\text {th }}$ Edition, Boston: Mc. Graw Hill.

Bryant, L, D.A. Jones, and S.K.Widener. 2004. "Managing Value Creation within the Firm: An Examination of Multiple Performance Measures", Journal of Management Accounting Research. Vol 10. 107-131

Cooper, Donald R. and Schindler, Pamela S. 2008. Business Research Methods. Boston: McGraw Hill.

Ferreira and Otley, David. 2005. The Design and Use of Management Control Systems:An Extended Framework for Analysis. SRRN. 1-28.

Ghozali, Imam. 2001. Aplikasi Analisis Multivariate Dengan Program SPSS, Semarang: BP UNDIP 
Intervensi

Pengendalian...
Hartman, F.G.H and Mass, Victor S. 2010. "Why Business Unit Controllers Create Budget Slack: Involvement in Management, Social Presure, and Machiavellianism", Behavioral Research in Accounting, Volume 22 (2) 27-49.

Jänkälä, Sinikka. 2005. The Use of Management Control Systems (MCS) Information in the Small Business Sector and the Relationship between MCS, Strategy and Performance. Proceeding of the $28^{\text {th }}$ Annual Congress of the European Accounting Association, 18-20 May 2005 in Gothenburg, Sweden. SRRN.

Kaplan, R.S and D.P. Norton. 1992. "The Balance Scorecard: Measures that Drive Performance", Harvard Business Reviewi, Vol.70 (1) 71-79.

Kaplan, R.S and D.P. Norton. 1993. "Putting the Balance Scorecard to Work", Harvard Business Review, Vol. 71 (5). 134-142.

KPMG LLP. 1999. "KPMG 1998 Fraud Survey". KPMG.

Kruse, D.L. 1992. "Provit Sharing and Productivity: Microeconomic Evidence from the United States", The Econimic Journal, January. 24-36.

Mackey, Alison, Tyson B.Mackey, and Jay.B.Barney. 2007. "Corporate Social Responsibility and Firm Performance: Investor Preferences and Corporate Strategies", Academy of Management Review, Vol.32 (3) 817-835

Malmi, T., \& Brown, D.A. 2008. "Management Control Systems as a Package Opportunities, Challenges and Research Directions", Management Accounting Research. Vol. 19. 287- 300.

Merchant, K.A. and Stede, W.A. 2007. Management Control Systems: Performance Measurement, Evaluation, and Incentives. $2^{\text {nd }}$ Edition. Prentice Hall. London.

O'Connor, Neale G., Vera-Muñoz, Sandra C., Chan, Francis. 2007. Performance Consequences of the "Fit" between Management Accounting and Control Systems and the Environment: Evidence from Publicly-Listed Chinese Firms. SRRN. 1-54.

Praptapa, Agung. 2009. The Art Of Controlling People: Strategi Mengendalikan Perusahaan. Jakarta: Gramedia Pustaka Utama.

Siegel, Gary and Marconi, Helene R. 1989. Behavioral Accounting. South-Western Publisher.

Zooping, Xiao. 2011. "Ownership-control rights divergence, government interven" tion and choice of capital structure: Empirical evidence from listed companies in China", Nankai Business Review International. 2 (3): 303 - 304. 